\title{
13. PLANKTONIC-FORAMINIFER ASSEMBLAGES ACROSS THE MIOCENE/PLIOCENE BOUNDARY AT DEEP SEA DRILLING PROJECT SITES 415 AND 416, AND CORRELATIONS WITH OTHER NORTH-ATLANTIC SUCCESSIONS
}

\author{
Maria Bianca Cita and Antonina Vismara-Schilling, Department of Geology and Paleontology, \\ University of Milan, Milan, Italy
}

\begin{abstract}
The Miocene/Pliocene boundary appears to correspond to an uncomformity at DSDP Site 415 (northern flank of Agadir Canyon), whereas it falls in a strongly condensed section at Site 416A (Moroccan Basin). Condensation at the latter site, however, may be artificial and due to the coring process. The duration of the sedimentary gap at Site 415 is estimated to be approximately 2 m.y. by correlation with DSDP Site 397 (upper continental rise off Cape Bojador), where several datum levels in a high-sedimentation-rate continuously cored hemipelagic sequence are calibrated with a magnetic-reversal sequence.

Forms transitional from Globorotalia miotumida to G. conomio$z e a$ were recorded; however, there were no typical specimens of the latter taxon, whose areal distribution in the eastern North Atlantic apparently does not extend beyond $33^{\circ}$ latitude.

The middle-Miocene (Serravallian) erosional episode, consistently recorded at drill sites in the eastern North Atlantic, interpreted as a response to the change in circulation pattern resulting from the cutoff of the Mediterranean seaway, might be recorded at Site 416 . Uncertainty of the exact position of cores with respect to sub-bottom depth, however, prevents a full documentation of its occurrence at this site.
\end{abstract}

\section{BACKGROUND}

The sample request submitted to the scientific staff of DSDP Leg 50 and resulting in the present contribution was motivated by our interest (1) in the Miocene/Pliocene boundary in the open ocean, compared to that recently typified stratigraphically in the Mediterranean area (Cita, 1975a), and (2) in the evolution of planktonicforaminifer faunas in the time interval corresponding to the isolation of the Mediterranean. Our previous experience on the eastern North Atlantic had shown that continuous marine successions straddling the Miocene/Pliocene boundary could be found (Cita, 1974; Salvatorini and Cita, 1979).

In particular, we were curious to investigate (1) whether at a latitude intermediate between that of Site $397\left(\sim 26^{\circ} \mathrm{N}\right)$ and that of Rabat $\left(\sim 33^{\circ} \mathrm{N}\right)$ (Figure 1) the same reduction in the number of species of keeled Globorotalia would be recorded when passing from the late Miocene to the early Pliocene, and (2) whether Globorotalia conomiozea, a supposedly medium- to highlatitude taxon, is present or not. This species in fact was consistently recorded in the Bou Regreg section near Rabat (Bossio et al., 1976; Wernli, 1977), whereas it was conspicuously absent in the Cape Bojador cores (DSDP Site 397) (Salvatorini and Cita, 1979; Mazzei et al.,
1979): its eventual occurrence in either the northern Site 416 or in the southernly 415 could permit tracing of the limits of its distribution in the eastern North Atlantic.

\section{SITE 415}

The four analyzed samples are from Sections 1 and 2 of Core 2, cut from 74 to 83.5 meters sub-bottom. A range chart of selected foraminifer species is represented in Figure 2, and some characteristic taxa are illustrated in Plate 1.

The sample from 29 to $31 \mathrm{~cm}$ in Section 1 of Core 2 yielded a rich and well-diversified faunal assemblage referable to Zone MP1 3 of Cita (1975b), which is characterized by the concurrent range of Globorotalia margaritae and $G$. puncticulata. This biozone belongs to the later part of the Zanclean Stage (early Pliocene). Also present are Globorotalia crassaformis and right-coiling Globigerina pachyderma. G. crassaformis overlaps the ranges of $G$. puncticulata and $G$. margaritae also at DSDP Site 397 (from Core 35 upward). The absence of Globigerina nepenthes suggests that the level under discussion postdates its last occurrence. Keeled Globorotalia belonging to the "cultrata" plexus are rare. The faunal assemblage is dominated by the genus Globigerina, by Globorotalia margaritae (also including the most advanced form G. margaritae evoluta), by Globig- 


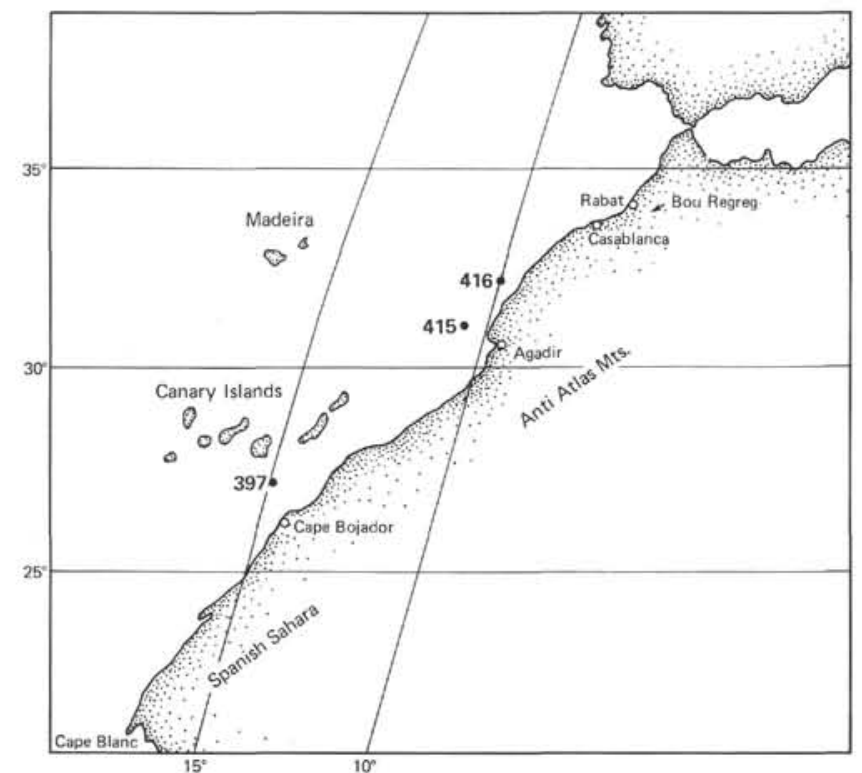

Figure 1. Sketch map showing the location of DSDP Sites 415, 416, and 397.

erinoides obliquus extremus, and by Globorotalia humerosa humerosa.

Samples 415-2-1, 115-117 cm and 415-2-2, 46-48 cm are very similar and consequently are discussed together. They are very rich in siliceous microfossils (radiolarians, siliceous sponge spicules) and show evidence of strong dissolution at depth, as proved by extended fragmentation of the foraminifer tests, and by thinned walls and enlarged pores. Dissolution is selective, which results in enrichment of solution-resistant taxa.

These samples yield typical specimens of Globoquadrina dehiscens whose last occurrence according to Berggren and Amdurer (1972) is a late Miocene biostratigraphic event (see also Berggren, 1977). The absence of Globigerinoides obliquus extremus and the occurrence of Globorotalia lenguaensis are suggestive of an early-Tortonian age; however, none of these biostratigraphic indications is unambiguous. Indeed, the absence of extremus could be due to dissolution, whereas the presence of lenguaensis (which becomes extinct prior to the first occurrence of G. tumida plesiotumida) could be due to reworking. In fact, in the lowermost investigated sample (Core $2, \mathrm{CC}, 21-23 \mathrm{~cm}$ ) the coexistence of G. obliquus extremus, of Globorotalia tumida plesiotumida, and of Sphaeroidinellopsis subdehiscens indicate Zone N.17, which is in agreement with the attribution of the radiolarian fauna to the Sticochorys peregrina Zone. The base of this radiolarian zone is calibrated to the middle part of paleomagnetic Epoch 6 and falls in the middle part of Zone N.17 (Ryan et al, 1974).

With reference to the zonation recently proposed by Salvatorini and Cita (1979), the two samples under discussion can be referred to the later part of Zone N.16, which has been emended in its upper boundary (first occurrence of Sphaeroidinellopsis seminulina paenedehiscens, instead of first occurrence of Globorotalia tumida plesiotumida) so that it is more restricted upward, corresponding to the lower part of Zone N.17. This interval corresponds to the latest part of the Tortonian Stage (see Ryan et al, 1974).

The lowermost sample is considered more biostratigraphically reliable than the two higher ones, because it is less affected by dissolution: we did not record any specimen referable to $G$. lenguaensis from the corecatcher sample. Siliceous microfossils, especially radiolarians, are less common than in the two overlying lateMiocene samples.

\section{SITE 416}

The three investigated samples are from Section 1 of Core 416A-1 (Figure 3). This core was cut from a nominal interval between 146 and 155.5 meters below sea floor but because of the coring technique employed it is possible that firm sediments from well above that interval entered the barrel inadvertently (see Site Report 416, this volume). The lowest sample $(78-80 \mathrm{~cm})$ was taken above an "apparent" uncomformity recorded by the shipboard paleontologists (Figure 4), corresponding to a time gap of some $6 \mathrm{~m} . \mathrm{y}$. This unconformity, however, could also be (at least in part) an artifact of coring.

The faunal assemblages are rich and diversified: planktonic foraminifers outnumber the benthic ones by orders of magnitude.

The topmost sample $(25-27 \mathrm{~cm})$ is referred to the upper part of the Globigerina nepenthes Interval-Zone of Salvatorini and Cita (1979), which is early Pliocene (lower Zanclean). Globorotalia margaritae is abundant and occurs with a large species, also fairly abundant, which we provisionally refer to as $G$. sp. cf. $G$. cibaoensis. Also present are specimens of $G$. humerosa humerosa, which is restricted to the Pliocene (Natori, 1976; Salvatorini and Cita, 1979).

The second sample from the top $(38-40 \mathrm{~cm})$ is referred to the earlier part of the $G$. nepenthes Zone, of the latest Miocene (late Messinian). It yields Globorotalia margaritae in lesser abundance than the topmost sample. We frequently recorded in this sample Globorotalia miotumida, also including specimens transitional to $G$. conomiozea. The latter is a middle- to high-latitude species originally described from New Zealand (Kennett, 1966). According to Jenkins (1971), to Berggren and Amdurer (1972) and to Berggren (1977), G. miotumida and $G$. conomiozea belong to the same lineage, the latter deriving from the former. The main difference between the two taxa is a greater ventral inflation of the chambers in G. conomiozea. Our identifications of G. miotumida were corroborated by examination of hypotypes from southern Australia, kindly made available by Dr. C. Mallett.

We recorded in this sample sparse specimens of Globorotalia crassaformis and of $G$. sp. cf. G. puncticulata, which we consider probable down-hole contaminants from higher Pliocene levels, but which could also be related to the highly condensed section.

The third and lowermost sample investigated (78-80 $\mathrm{cm}$ ) does not yield $G$. margaritae, and is referable to Zone N.17 (Sphaeroidinellopsis seminulina paenedehiscens Zone of Salvatorini and Cita, 1979), of late-Miocene age. 


\begin{tabular}{|c|c|c|c|c|}
\hline & \multicolumn{4}{|c|}{ Core $415-2$} \\
\hline & \multicolumn{2}{|c|}{ Section 1} & \multicolumn{2}{|c|}{ Section 2} \\
\hline & $29-31 \mathrm{~cm}$ & $115-117 \mathrm{~cm}$ & $46-48 \mathrm{~cm}$ & $21-23 \mathrm{~cm}$ \\
\hline Globigerina apertura & $\mathrm{X}$ & & & $\mathrm{X}$ \\
\hline G. bulbosa & $\mathrm{X}$ & $\mathrm{X}$ & $\mathrm{X}$ & $\mathrm{X}$ \\
\hline G. bulloides & $\mathrm{X}$ & $\mathrm{X}$ & $\mathrm{X}$ & $\mathrm{X}$ \\
\hline G. falconensis & $X$ & $\mathrm{X}$ & & $\mathrm{X}$ \\
\hline G. microstoma & $\mathrm{X}$ & $X$ & $\mathrm{X}$ & $\mathrm{X}$ \\
\hline G. nepenthes & & $\mathrm{X}$ & $\mathrm{X}$ & \\
\hline $\begin{array}{l}\text { G. pachyderma } \\
\text { G. quinqueloba }\end{array}$ & $\begin{array}{l}X \\
X\end{array}$ & $\mathrm{X}$ & $\mathrm{X}$ & $\mathrm{X}$ \\
\hline Globigerinoides obliquus extremus & $\mathrm{X}$ & & & $\mathrm{X}$ \\
\hline G. obliquus obliquus & $\mathrm{X}$ & $\mathrm{X}$ & $\mathrm{X}$ & $\mathrm{X}$ \\
\hline G. quadrilobatus & & $\mathrm{X}$ & $\mathrm{x}$ & $\mathrm{X}$ \\
\hline G. ruber & $\mathrm{X}$ & $\mathrm{X}$ & & $\mathrm{X}$ \\
\hline G. sacculifer & & $\mathrm{X}$ & $\mathrm{X}$ & $\mathrm{X}$ \\
\hline G. trilobus & & $\mathrm{X}$ & $\mathrm{X}$ & $\mathrm{X}$ \\
\hline Globorotalia acostaensis & $\mathrm{X}$ & $\mathrm{X}$ & $\mathrm{X}$ & $\mathrm{X}$ \\
\hline G. continuosa & & $\mathrm{X}$ & & \\
\hline G. crassaformis & $\mathrm{X}$ & & & \\
\hline G. cultrata group & $\mathrm{X}$ & $\mathrm{X}$ & $\mathrm{X}$ & $\mathrm{X}$ \\
\hline G. humerosa humerosa & $\mathrm{X}$ & & & \\
\hline G. humerosa praehumerosa & $\mathrm{X}$ & $\mathrm{X}$ & & $\mathrm{X}$ \\
\hline G. lenguaensis & & $\mathrm{X}$ & $\mathrm{X}$ & \\
\hline $\begin{array}{l}\text { G. margaritae evoluta } \\
\text { G. margaritae margaritae }\end{array}$ & $\begin{array}{l}X \\
X\end{array}$ & & & \\
\hline $\begin{array}{l}\text { G. margaritae margaritae } \\
\text { G. merotumida }\end{array}$ & & & $\mathrm{X}$ & \\
\hline G. moitumida & $\mathrm{X}$ & & & \\
\hline G. miozea & & $\mathrm{X}$ & & \\
\hline G. obesa & $\mathrm{X}$ & $\mathrm{X}$ & $\mathrm{X}$ & \\
\hline G. tumida plesiotumida & & & $\mathrm{X}$ & $\mathrm{X}$ \\
\hline G. puncticulata & $\mathrm{X}$ & & & \\
\hline G. scitula & $\mathrm{X}$ & $\mathrm{X}$ & $X$ & $\mathrm{X}$ \\
\hline Globigerinita glutinata & $\mathrm{X}$ & $\mathrm{X}$ & $\mathrm{X}$ & $\mathrm{X}$ \\
\hline Globoquadrina altispira & $\mathrm{X}$ & $\mathrm{X}$ & $\mathrm{X}$ & $\mathrm{X}$ \\
\hline Globoquadrina dehiscens & & $\mathrm{X}$ & $\mathrm{X}$ & $\mathrm{X}$ \\
\hline Hastigerina siphoniphera & $\mathrm{X}$ & $\mathrm{X}$ & & \\
\hline Orbulina bilobata & $\mathrm{X}$ & & & \\
\hline O. suturalis & $X$ & $\mathrm{X}$ & $\mathrm{X}$ & \\
\hline O. universa & $\mathrm{X}$ & $\mathrm{X}$ & $\mathrm{X}$ & $\mathrm{X}$ \\
\hline Sphaeroidinellopsis seminulina seminulina & $\mathrm{X}$ & & & \\
\hline S. seminulina paenedehiscens & $\mathrm{X}$ & & & \\
\hline S. subdehiscens & & $\mathrm{X}$ & $\mathrm{X}$ & $\mathrm{X}$ \\
\hline Zone & MPc 3 & & N.17 & \\
\hline Series & Pliocene & & Miocene & \\
\hline Stage & Zanclean & & Tortonian & \\
\hline
\end{tabular}

Figure 2. Distribution of 40 species and subspecies of planktonic foraminifers in Core 415-2.

\section{CORRELATIONS}

\section{Correlation Between Sites $\mathbf{4 1 5}$ And $\mathbf{4 1 6}$}

The correlation is shown in Figure 4. We believe that all the investigated samples from Site 416 are older than the youngest studied sample from Site 415 , and younger than the remaining three samples of Sites 415 . There is evidence of a highly condensed sequence at Site 416, where biozones follow in their correct order, although strongly condensed and with some anomalies. This condensation may be real (as represented in Figure 4), or it may be artificial.

On the flank of the Agadir Canyon (Site 415) there is a biostratigraphically documented hiatus corresponding at least to the Globigerina nepenthes Interval-Zone which extends from the middle part of paleomagnetic Epoch 5 to the middle part of the Gilbert epoch (see Mazzei et al, 1979). The hiatus probably extends back in time to include the latter part of Zone N.17. Indeed, we referred to Zone N.17 both the lower part of the investigated interval at Site 415, and the lowermost sample from Site 416. Although the difference is so small as not to be proved paleontologically in a straightforward manner, it is strongly supported by the difference in dissolution, and by content of biogenic silica. Dissolution is much stronger at the shallower Site 415, where siliceous microfossils are abundant, whereas it is conspicuously absent at Site 416. These observations suggest (1) that the sediments under discussion are not contemporaneous, and (2) that the sediments from Site 415 are older. 


\begin{tabular}{|c|c|c|c|}
\hline & \multicolumn{3}{|c|}{ Core 416A-1 } \\
\hline & \multicolumn{3}{|c|}{ Section 1} \\
\hline & $25-27 \mathrm{~cm}$ & $38-60 \mathrm{~cm}$ & $78-80 \mathrm{~cm}$ \\
\hline Globigerina bulbosa & $\mathrm{X}$ & $\mathrm{X}$ & $\mathrm{X}$ \\
\hline G. bulloides & $\mathrm{x}$ & $\mathrm{X}$ & $\mathrm{X}$ \\
\hline G. falconensis & $\mathrm{x}$ & $\mathrm{X}$ & $\mathrm{X}$ \\
\hline G. microstoma & $\mathrm{X}$ & $\mathrm{X}$ & $\mathrm{X}$ \\
\hline \multirow{2}{*}{ G. nepenthes } & $\mathrm{X}$ & $\mathrm{X}$ & $\mathrm{X}$ \\
\hline & $\mathrm{X}$ & & \\
\hline G. quinqueloba & $\mathrm{x}$ & & \\
\hline Globigerinoides obliquus extremus & $\mathrm{X}$ & $\mathrm{X}$ & $\mathrm{X}$ \\
\hline G. obliquus obliquus & $\mathrm{X}$ & $\mathrm{X}$ & $\mathrm{X}$ \\
\hline G. quadrilobatus & $\mathrm{X}$ & $\mathrm{X}$ & $\mathrm{X}$ \\
\hline G. ruber & $\mathrm{X}$ & & $\mathrm{X}$ \\
\hline G. sacculifer & $\mathrm{X}$ & $\mathrm{X}$ & $\mathrm{X}$ \\
\hline G. trilobus & $\mathrm{X}$ & $\mathrm{X}$ & $\mathrm{X}$ \\
\hline & $\mathrm{X}$ & $\mathrm{X}$ & $\mathrm{X}$ \\
\hline & & $\mathrm{X}$ & \\
\hline $\begin{array}{l}\text { G. crassaformis } \\
\text { G. cultrata group }\end{array}$ & $\mathrm{X}$ & $\mathrm{X}$ & $\mathrm{X}$ \\
\hline G. humerosa humerosa & $\mathrm{X}$ & $\mathrm{X}$ & \\
\hline G. humerosa praehumerosa & $\mathrm{X}$ & $\mathrm{X}$ & $\mathrm{X}$ \\
\hline G. margaritae margaritae & $\mathrm{X}$ & $\mathrm{X}$ & \\
\hline G. merotumida & $\mathrm{X}$ & $\mathrm{X}$ & $\mathrm{X}$ \\
\hline G. miotumida & $\mathrm{X}$ & $\mathrm{X}$ & $\mathrm{X}$ \\
\hline \multirow{2}{*}{$\begin{array}{l}\text { G. miozea } \\
\text { G. sp. cf. G. miozea cibaoensis }\end{array}$} & $\mathrm{X}$ & $\mathrm{X}$ & $\mathrm{X}$ \\
\hline & $\mathrm{X}$ & & \\
\hline \multirow{2}{*}{$\begin{array}{l}\text { G. tumida plesiotumida } \\
\text { G. puncticulata }\end{array}$} & $\mathrm{X}$ & & \\
\hline & & $\mathrm{X}$ & \\
\hline \multirow{2}{*}{$\begin{array}{l}\text { G. scitula } \\
\text { G. sphericomiozea }\end{array}$} & $\mathrm{X}$ & $\mathrm{X}$ & $\mathrm{X}$ \\
\hline & & $\mathrm{X}$ & \\
\hline \multirow{8}{*}{$\begin{array}{l}\text { Globigerinita glutinata } \\
\text { Globoquadrina altispira } \\
\text { Hastigerina siphoniphera } \\
\text { Orbulina suturalis } \\
\text { O. universa } \\
\text { Sphaeroidinellopsis seminulina seminulina } \\
\text { S. seminulina paenedehiscens } \\
\text { S. subdehiscens }\end{array}$} & $\mathrm{x}$ & $\mathrm{X}$ & $\mathrm{X}$ \\
\hline & $\mathrm{X}$ & $\mathrm{X}$ & $\mathrm{X}$ \\
\hline & & $\mathrm{X}$ & \\
\hline & $\mathrm{X}$ & $\mathrm{X}$ & $\mathrm{X}$ \\
\hline & $\mathrm{X}$ & $\mathrm{X}$ & $\mathrm{X}$ \\
\hline & $\mathrm{X}$ & & $\mathrm{X}$ \\
\hline & $\mathrm{X}$ & $\mathrm{X}$ & $\mathrm{X}$ \\
\hline & & & $\mathrm{X}$ \\
\hline Zone & G. nep & nthes & N.17 \\
\hline & Interv & -Zone & (emended) \\
\hline Series & $\begin{array}{l}\text { Early } \\
\text { Pliocene }\end{array}$ & Late & iocene \\
\hline Stage & Zanclean & Mes & inian \\
\hline
\end{tabular}

Figure 3. Distribution of 35 species and subspecies of planktonic foraminifers in Core 416 A-1.

In fact, previous studies by Berger and Von Rad on the North Atlantic (1972) showed that CCD progressively shallows as a function of increasing time in the Miocene, so that one can expect to find more dissolved sediments in the lower part of Zone N.17, referable to the Tortonian, than in its upper part, referable to the Messinian. At Site 397, where quantitative studies were carried out on several parameters connected with dissolution, the highest dissolved sediments were recorded in the late Tortonian (Cita and Spezzi Bottiani, 1979), and this agrees well with the present observations.

In conclusion, the sequence investigated at Site 416 is highly condensed; however, no significant time gap could be proved.

\section{Correlation with the Bou Regreg Section of Central Morocco}

A continuous marine section straddling the Miocene/Pliocene boundary has been described by several authors along the valley of the Bou Regreg River, near Rabat (see Feinberg and Lorenz, 1970; Cita, 1974; Bossio et al., 1976; Wernli, 1977). The outcrops are in part discontinuous, and the transitional beds between a silty marl unit of late-Miocene age and a blue marl unit of early-Pliocene age are not well exposed; however, the continuity of the section is fairly good.

The rich and diversified foraminifer assemblage of the late Miocene yields Globorotalia conomiozea in 


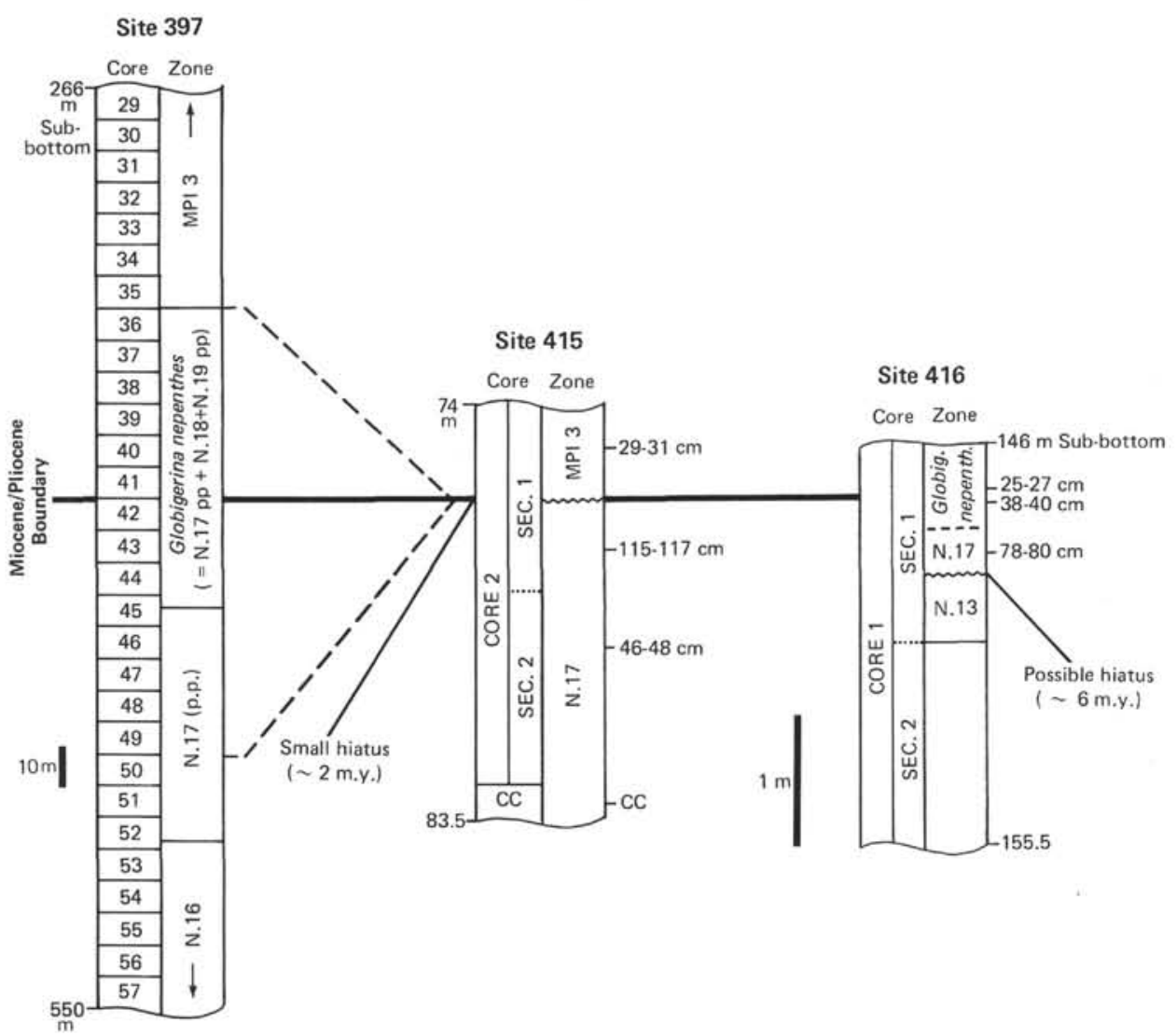

Figure 4. Correlation of the interval encompasing the Miocene/Pliocene boundary at DSDP Sites 397 (Cape Bojador), 415 (Agadir Canyon), and 416 (Moroccan Basin). "Condensation"' at Site 416 could have resulted from coring.

some abundance, along with several other taxa belonging to the Globorotalia cultrata plexus. G. margaritae is first recorded in a transitional unit characterized by cyclic alternations of coarse sands and silty marls. The first occurrence of $G$. margaritae stratigraphically overlies a level where a rapid change in the coiling ratio of Globorotalia acostaensis from senestral (below) to dextral (above) is recorded. Both biostratigraphic events were also recorded at Site 397, respectively in the middle part of paleomagnetic Epoch 5 and at the base of Epoch 5 (Mazzei et al., 1979). The dominantly left-coiling of $G$. acostaensis, recorded in the core-catcher sample of Core 415-2, points to an age older than Epoch 5.

The condensed nature of the sections penetrated at both Sites 415 and 416 prevents following in detail the evolution of foraminifer faunas. The early Pliocene recorded at Site 416 can be correlated with the exposed section at Briqueterie de Sale, on the right bank of the Bou Regreg, whereas the early Pliocene of Site 415 is younger (Zone MP1 3, characterized by the concurrent range of G. margaritae and G. puncticulata); indeed, all the exposed section of the Bou Regreg predates the first occurrence of $G$. puncticulata.

\section{Correlation With DSDP Site 397}

The few samples from Sites 415 and 416 here considered can be correlated with the expanded late-Neogene succession continuously cored off Cape Bojador (DSDP Site 397), where biostratigraphic zonations could be calibrated to the paleomagnetic stratigraphy (see Ryan, von Rad, et al., 1979; Mazzei et al., 1979, in press). Figure 4 shows such a correlation. In particular, the topmost investigated sample from Site $415(29-31 \mathrm{~cm}$ in Section 1 of Core $415-2$, approximately $74 \mathrm{~m}$ sub-bottom and approximately $2868 \mathrm{~m}$ sub-sea) can be correlated with Cores 34 to 35 of Site 397 ( 313 to $332 \mathrm{~m}$ sub-bottom, 3223-3242 m sub-sea).

The topmost sample from 416A $(25-27 \mathrm{~cm}$ in Section 1 of Core $1 ; 146 \mathrm{~m}$ sub-bottom, approximately $4337 \mathrm{~m}$ sub-sea) can be correlated with Cores 38 to 39 of Site 397 (351-370 m sub-bottom, 3261-3280 m sub-sea).

A precise correlation of the late-Miocene samples is hampered (1) by the condensed sedimentary succession at Sites 415 and 416 , and (2) by dissolution, especially at the shallower Site 415.

Factor (1) results in abnormal occurrences of taxa whose ranges do not overlap in more-expanded sections. For instance, Globorotalia miotumida does not co-exist with G. margaritae at Site 397 according to Salvatorini and Cita (1979), whereas both taxa are recorded together at 415 and 416 . Factor (2) acts as "noise" in the biostratigraphic record.

It is worthwhile mentioning that the Miocene section of Site 397 is the most complete one from the eastern 
Atlantic; however, one interval with slumps (within the late-Miocene foraminifer Zone N.16) and two minor hiatuses in the middle Miocene could be documented biostratigraphically.

The gap possibly existing at Site 416 in the Serravallian, where it encompasses Zone N.15, could be correlated with a similar one recorded not only at the upslope Site 369 (off Cape Bojador), but also in the Sierra Leone Rise (Site 366; Leg 41) and in the Rio Grande Rise (Site 357; see Boersma, 1977; Berggren, 1977). The wide areal distribution of this submarine erosional phase of Serravallian age in the North Atlantic is pointed out. The hypothesis is put forward that this erosion is related to an important change in oceanographic regime and geostrophic thermohaline current pattern, related to the closure of the Mediterranean to the east, which resulted in the interruption of the equatorial current system, and hence in a reactivation of the North/South Atlantic boundary currents.

\section{ACKNOWLEDGMENTS}

Financial support has been provided by Consiglio Nazionale delle Ricerche through Grant 77.00763 .89 to Cita. Technical assistance by G. Spezzibottiani, A. Rizzo and G. Chiodi is acknowledged.

We thank E. Vincent, I. Premoli-Silva, and G. Salvatorini for critical revision of the text.

\section{REFERENCES}

Berger, W. and von Rad, U., 1972. Cretaceous and Cenozoic sediments from the Atlantic Ocean, In Hayes, D. E., Pimm, A. C., et al., Initial Reports of the Deep Sea Drilling Project, v. 14: Washington (U.S. Government Printing Office), p. 787.

Berggren, W. A., 1977. Late Neogene planktonic foraminiferal biostratigraphy of DSDP Site 357 (Rio Grande Rise). In Perch-Nielsen, K., Supko, P., et. al., Initial Reports of the Deep Sea Drilling Project, v. 39: Washington (U.S. Government Printing Office), p. 591.

Berggren, W. A., and Amdurer, M., 1972. Late Paleogene (Oligocene) and Neogene planktonic foraminiferal biostratigraphy of the Atlantic Ocean (Lat. $30^{\circ} \mathrm{N}$ to $30^{\circ} \mathrm{S}$ ). Riv. Ital. Paleont., v. 79, No. 3, p. 337.

Bizon, G., and Bizon, J. J., 1972. Atlas des principaux foraminifères planctoniques du bassin méditerranéen (Oligocène à Quaternaire): Paris (Technip).

Boersma, A., 1977. Cenozoic planktonic foraminifera. DSDP Leg 39 (South Atlantic). In Perch-Nielsen, K., Supko, P., et al., Initial Reports of the Deep Sea Drilling Project, v. 39: Washington (U.S. Government Printing Office), p. 567.

Bossio, A., El Bied Rakich, K., Giannelli, L., Mazzei, R., Russo, R. and Salvatorini, G., 1976. Corrélation de quelques sections stratigraphiques du Mio-Pliocène de la zone atlantique du Maroc avec le stratotypes du Bassin Méditerranéen sur la base des foraminifères planctoniques, nanno- plancton calcaire et ostracodes. Atti Soc. Tosc. Sc. Nat. Mem., v. 83 , p. 121 .

Cita, M. B., 1974. Il significato geodinamico della crisi di salinita del Miocene terminale nel Mediterraneo. Relazione scientifica, 1974, p. 14. 1975a. The Miocene/Pliocene boundary. History and definition. In Late Neogene Epoch Boundaries: Micropaleontology, Spec. Pub. No. 1, p. 24.

1975b. Planktonic foraminiferal biozonation of the Mediterranean Pliocene deep-sea record. A revision. Riv. Ital. Paleont., v. 81 , No. 4 , p. 527

Cita, M. B. and Spezzi Bottiani, G., 1979. Late Neogene paleoenvironment studies on carbonate content, grain sizes, and dissolution, Cores 1-57 (DSDP Site 397). In Ryan, W., von Rad, U., et al., Initial Reports of the Deep Sea Drilling Project, v. 47, Part 1: Washington (U.S. Government Printing Office), p. 671-682.

Feinberg, H., and Lorenz, H. G., 1970. Nouvelles données stratigraphiques sure le Miocène supérieur et le Pliocène du Maroc nord-occidental. Notes Serv. Géol. Maroc, v. 30, no. 225 , p. 21

Jenkins, D. G., 1971. New Zealand Cenozoic planktonic foraminifera. New Zealand Geol. Survey Paleont. Bull., v. 42, p. 278.

Kennett, J. P., 1966. The Globorotalia crassaformis bioseries in North Westland and Marlborough, New Zealand. Micropaleontology, v. 12 , no. 2 , p. 235.

Mazzei, R., Raffi, I., Rio, D., Hamilton, N., and Cita, M. B., 1979. Calibration of late Neogene calcareous plankton datum planes with the paleomagnetic record of Site 397 and correlation with Moroccan and Niediterranean sections. In Ryan, W., von Rad, U., et al, Initial Reports of the Deep Sea Drilling Project, v. 47, Part 1: Washington (U.S. Government Printing Office), p. 375-390.

Natori, H., 1976. Planktonic foraminiferal biostratigraphy and datum planes in the Late Cenozoic sedimentary sequence in Okinawa-Jima, Japan. In Progress in Micropaleontology: Micropaleontology, Spec. Pub., no. 2, p. 214.

Ryan, W. B. F., Cita, M. B., Dreyfus Rawson, M., Burckle, L. H., and Saito, T., 1974. A paleomagnetic assignment of Neogene Stage boundaries and the development of isochronous datum planes between the Mediterranean, the $\mathrm{Pa}$ cific and Indian oceans in order to investigate the response of the world Ocean to the Mediterranean "salinity crisis". Riv. Ital. Paleont., v. 80 , no. 4 , p. 631.

Ryan, W., von Rad, U., et al., 1979. Initial Reports of the Deep Sea Drilling Project, v. 47, Part 1: Washington (U.S. Government Printing Office).

Salvatorini, G. and Cita, M. B., 1979. Miocene foraminiferal stratigraphy, DSDP Site 397. (Cape Bojador, North Atlantic) In Ryan, W., von Rad, U., et al., Initial Reports of the Deep Sea Drilling Project, v. 47, Part 1: Washington (U.S. Government Printing Office) p. 317-374.

Stainforth, R. M., Lamb, J. L., Luterbacher, H. P., Beard, J. H., and Jeffords, R. M., 1975. Cenozoic planktonic foraminiferal zonation and characteristics of index forms. Univ. Kansas Paleont. Contr., v. 12, no. 2.

Wernli, R., 1977. Le Foraminiferes planctoniques de la limite Mio-Pliocene dans les environs de Rabat (Maroc). Eclogae Geol. Helv., v. 70 , no. 1, p. 143. 



\section{PLATE 1}

Figures 1-4, 7 Globorotalia miotumida Jenkins.

1. spiral view, $\times 90$. Sample 416A-1-1, 78-80 $\mathrm{cm}$. Zone N.17, Tortonian.

2. as above.

3. as above, in umbilical view.

4. as above, in side view.

7. as above, in spiral view.

Figures 5, 6 Globorotalia tumida plesiotumida Blow and Banner.

5. spiral view, $\times 90$. Sample $425-2$, CC, $21-23$ $\mathrm{cm}$. Zone N.17, Tortonian.

6. as above, in umbilical view.

Figures 8-10 Globorotalia miozea miozea Finlay.

8. spiral view, $\times 90$. Sample 416 A-1-1, 78-80 $\mathrm{cm}$. Zone N.17, Tortonian.

9. as above, in umbilical view.

10. as above in side view.

Figures 11-14 Globorotalia cultrata (d'Orbigny).

11. spiral view, $\times 45$. Sample 415-2, CC, 21-23 $\mathrm{cm}$. Zone N.17, Tortonian.

12. as above, in umbilical view.

13. as above, in spiral view.

14. as above, in umbilical view. 
PLATE 1
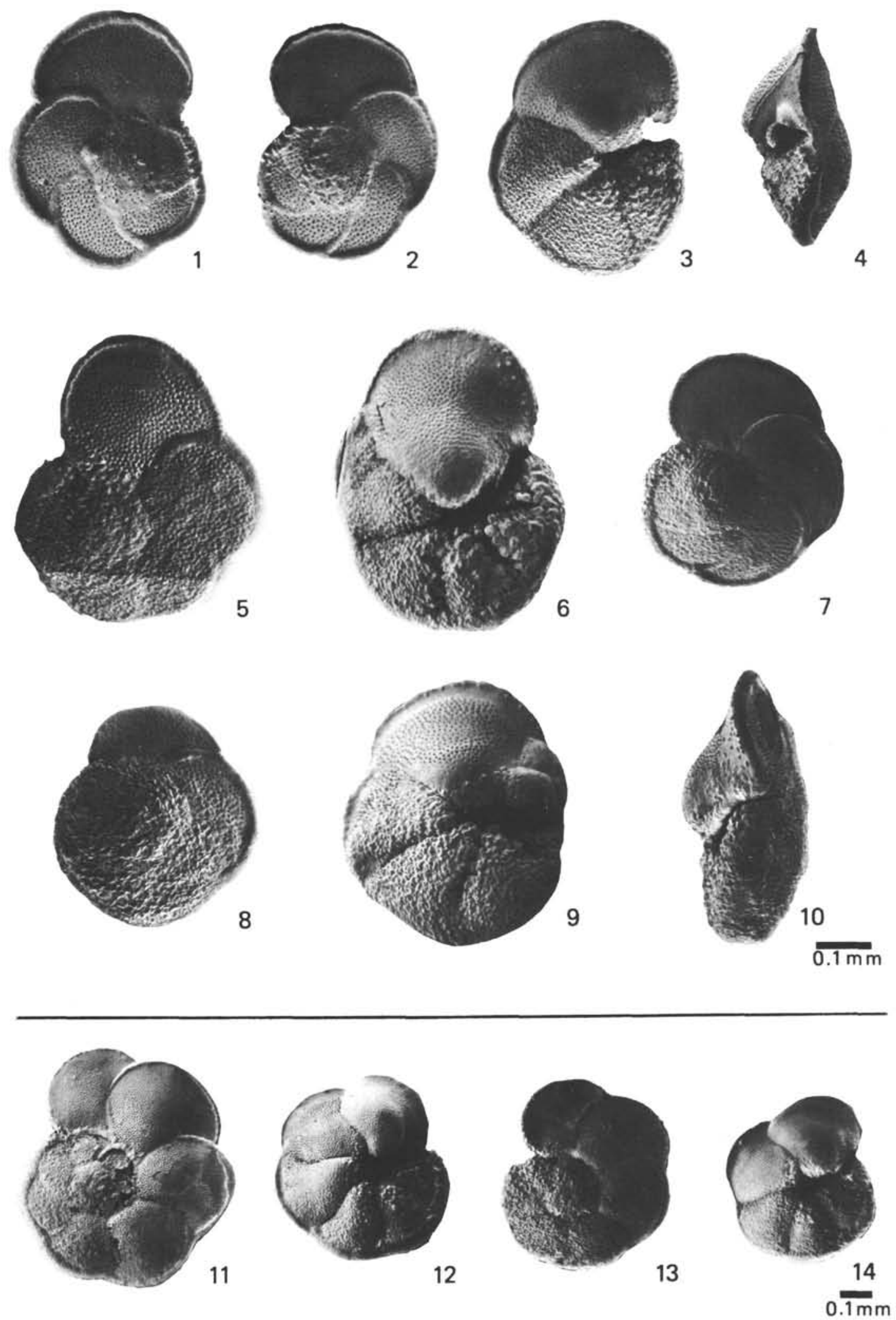